\title{
Pre-Service Teachers' Classroom Management Styles And Senior Secondary Students' Performance In General Mathematics In Rivers State, Nigeria
}

\author{
Akpobome, Enoh Jephthah ", George, Nchelem Rosemary ${ }^{* *}$ \\ * Department Of Curriculum Studies And Instructional Technology, Faculty Of Education, Ignatius Ajuru University Of Education Port Harcourt \\ Rivers State Nigeria \\ ** Ph.D, Department Of Mathematics/Statistics, Faculty Of Natural And Applied Sciences, Ignatius Ajuru University Of Education Port Harcourt \\ Rivers State Nigeria
}

DOI: 10.29322/IJSRP.11.12.2021.p12062

http://dx.doi.org/10.29322/IJSRP.11.12.2021.p12062

\begin{abstract}
The study investigated the relationship between preservice teachers' classroom management style and senior secondary students' performance in general mathematics in Rivers state Nigeria. A sample size of ninety four (94) final year preservice mathematics teachers was used for the study. The census sampling technique was employed to draw the sample. Six research questions were answered and six hypotheses were tested at 0.05 level of significance. Two instruments were used to collect data namely the "Pre-service Mathematics Teachers' Classroom Management Questionnaire" (PMTCMQ) and "Mathematics Performance Test Grade Inventory" (MPTGI). The validated PMTCMQ was used to determine pre-service teachers" classroom questioning technique, classroom interaction, classroom leadership style, classroom task time scheduling, classroom instructional techniques and classroom organization while the MPTGI constituted the source from which the student performance was extracted. The study employed the correlational survey design. The data collected was analyzed using the Pearson Product Moment Correlation statistical tool. The finding showed that pre-service teachers' questioning technique significantly influenced the student performance. Pre-service teachers' task time scheduling and interaction did not have significant influence on student performance. Based on the findings it was recommended that pre-service teachers should be coached on how to maintain classroom management styles during micro-teaching sessions.
\end{abstract}

Index Terms- Pre-serviceTeacher, Mathematics, Management, Performance, Classroom.

\section{INTRODUCTION}

$\mathrm{T}$ he classroom is the official arena where the implementation of the mathematics curriculum takes place. It therefore implies that the classroom atmosphere should be well moderated for a successful learning outcome to manifest. This depends on the teachers' classroom management style. Classroom management is critical to students' classroom progress and the attainment of educational goals. Writing on a chalkboard, discussing with students, demonstrating an instructional procedure, supervising student's class work, piloting an instructional process, reading and marking assignments, time scheduling for instructional activities, classroom control, questioning techniques, classroom interaction, and maintaining classroom discipline are all examples of teaching and learning activities which the mathematics teacher can involve in. According to Martin and Sass (2010), if discipline and conduct are not adequately addressed during instruction, failure is inevitable, and these might be accountable for the failure documented at various levels in mathematics.

According to Menenu (2018), one of the most important aspects of classroom management is discipline. Since students conduct is connected to academic performance, it is critical for the mathematics instructor to use appropriate classroom management strategies in order to effectively manage the mathematics class. This is because poor classroom management may have a detrimental influence on students' mathematics education, learning, and performance. Students' academic performance is boosted by a well-managed classroom that supports effective teaching and learning. Classroom management, according to Mayer (2018), refers to the tactics and practices used by educators to keep a classroom atmosphere conducive for student achievement and learning. A capable mathematics teacher is required to establish and implement classroom management strategies that they are familiar within their classes. Ukandu and Kehinde (2020) defined classroom management as a set of procedures that, if followed, should assist the teacher in maintaining classroom order. These procedures include both antecedent and resulting procedures that can be combined to provide a comprehensive approach to classroom management.

Pre-service teacher training is a set of educational programmes designed to prepare future teachers to enter the profession at a certain level of education. Teachers who do not fulfill officially recognized training criteria and enrolled in a teacher training school to achieve accreditation while working as a teacher are not covered by pre-service training (UNESCO, 2021). Students' practice teaching is a practical teaching activity in which student-teachers are given the chance to display and enhance their pedagogical abilities in a real-world setting over a certain period of time. Pre-service teachers are required to go to schools for practice teaching under the supervision of a superior teacher in order to get the experience needed to qualify as a teacher. In this regard, mathematics pre-service teachers are 
typically expected to be responsive to their own abilities, know the names of students, practice approach, methods, and procedure, successfully manage the teaching-learning process, use time effectively, have communication skills, acquire classroom management skills, carry out assessment and evaluation, and manage inappropriate student behaviours in the context of the teaching-learning process of the practice teaching internship.

Practice teaching, according to Francis, Philip, and Francis (2017), helps pre-service teachers gain understanding and interest in teaching, as well as personal development skills such as decision-making, critical thinking, increased self-confidence and self-esteem. Planning, teaching, watching, and positive criticism are all part of microteaching. Teaching, feedback, re-planning, reteaching, and re-feedback are five steps that can be included (Putri, Ferlya \& Yusnila, 2018). Furthermore, by combining theory and practice, the micro-teaching session organizes the model for preservice teachers and builds their confidence in teaching (Ismail, 2011). Furthermore, pre-service teachers will gain additional practical experience in the micro-teaching class in addition to learning and reflecting on various teaching strategies. Pre-service teachers benefit from microteaching because it gives them valuable teaching experience and helps them understand the benefits and connections between theory and practice. Microteaching is also set up as a safe training environment where pre-service teachers can practice their teaching skills before taking over the actual classroom.

Pre-service teachers are posted to schools to conduct real teaching in the classroom after completing the microteaching course. This internship is classified as a teaching internship. Preservice teachers are exposed to real-world classroom situations in which they are required to demonstrate their knowledge of teaching, socialising, negotiating, and other managerial skills. Preservice teachers' training is a crucial period in which they gain their first teaching experience, which they will use throughout their career. Pre-service teachers can gain desired experiences by conducting teaching practise in a real classroom setting. The practise school is the ideal location for practising teaching (Shafqat \& Muhammad, 2015). This environment is used to familiarise pre-service teachers with their teaching professions, schools, teachers, and students. Duties, obligations, and reciprocal expectations exist between pre-service instructors, teachers, school officials, and students.

The classroom is where all of a school's academic activities that connect teaching and learning take place. As a result, it is critical for a mathematics teacher to use their understanding of classroom management style for classroom teaching in order to fulfil the aim of teaching and learning. Classroom management is a prerequisite for achieving instructional objectives and safeguarding the well-being of students who are the focus of teaching and learning activities. The planning of a mathematics curriculum is not complete until it is implemented. The classroom is where the curriculum is implemented. As a result, it is critical for pre-service teachers to be familiar with a variety of classroom management techniques in order to establish a productive and conducive atmosphere in which the teaching/learning process may be effective and learners can master mathematics curricular contents. The role of the pre-service mathematics teacher is critical to the overall mathematics learning process. The primary goal of pre-service mathematics teachers is to provide opportunities for prospective teachers to improve their professional competency by gradually taking on more full-fledged teacher responsibilities under the supervision of experienced personnel and in accordance with their readiness and needs. Pre-service teachers teaching, in particular, is a proving ground for both the pre-service teacher and the teacher education programme. This activity is essential for preservice teachers' preparation. No wonder, participation in preservice practice teaching exercise is made compulsory and student-teachers must have passed the necessary examination for pre-service program before graduation.

Classroom management style involves all the activities done by the teacher to create a safe and motivating learning environment. These include management of space, time allotted to each subject, students' behavior, social relations among class members, task, and materials, leadership style. Classroom management styles are perhaps one of the most sensitive activity in the teaching and learning process. The process of teaching and learning mathematics in the classroom is the primary responsibility of the pre-service mathematics teacher, whereas other activities are secondary. The pre-service mathematics teacher is required to put learning theories and other teaching and learning concepts into practice. The capacity to properly control the classroom during instruction is one of the cornerstones of teaching and learning mathematics.

When teachers use an effective classroom management strategy, they reduce the behaviours that obstruct learning for both individual students and groups of students, while maximising the behaviours that facilitate or enhance learning. Teachers find it a lot more difficult in managing classroom because some schools have children with special needs and emotional disorder/ difficulties found in their class. In an attempt to strike a balance in managing such children, some apply management styles which become detrimental (Ducharme, 2007; Parsonson, 2012). Some of the management styles may produce immediate result but may lack the potency to endure. Classroom management expresses the ability of the teacher to coordinate students' behavior and their social relationship among class members for optimal academic performance. Effective classroom management style will establish rules for managing the class. Procedures for completing activities in the classroom are more effective. Teachers should think in terms of observable student responsibilities when formulating rules and maintaining procedures (Patric, 2002). In order to create positive and interactive learning environments, teachers must also consider their own responsibilities. The classroom management style is essential bridge between the student, the teacher, and the mathematics curriculum content. It is the medium via which classroom activities are organized and controlled. Classroom management necessitates the teacher to organize and control the learning outcome, the learner, the learning environment and the learning process. The pre-service mathematics teacher becomes central in discussing classroom management style as this will influence and impact the students' performance in and attitude toward mathematics. It is based on this backdrop that the researchers sought to investigate pre-service teachers' management styles and the academic performance of senior secondary school students in general mathematics. 


\section{STATEMENT OF THE STUDY}

The importance of classroom management style in achieving educational goals should be discussed on a regular basis. The classroom management style, as well as the process of teaching and learning, has evolved over time. Effective classroom management puts the teacher in charge of the classroom and ensures the order and safety that are necessary for teaching and learning. Until now, various educational reforms, such as the 1977 National Policy on Education, which was revised in 2014, have failed to mention or address classroom management and the relationship between students' academic performance and classroom management style.

When classroom management methods are employed in the teaching-learning process to create the desired atmosphere, the desired outcome is unavoidable, and so performance is accomplished. The major goal of this research was to find a link between pre-service teacher classroom management style and senior secondary school general mathematics achievement. The society generally holds teachers accountable for every aspect of student performance because of what society perceive of the teacher. Classroom management style plays a key role in curriculum implementation. The pre-service teacher needs to be equipped with various effective classroom management styles inorder to make all the students active and participate during teaching/learning process. Individuals have different personality traits as some are introvert and some extrovert, some students are deviant while some have quality behavior, some have above average ability while some have just average or below average ability. It is the duty of the teacher to develop management styles that will harness these various characteristics to create a working and conducive environment for learning.

When the pre-service mathematics teacher lacks classroom management style there is bound to be poor performance of students in that class and especially in general mathematics. Mathematics is one of the core subjects that all students must pass at credit level to allow furtherance of their educational pursuit. In the light of the above it becomes very necessary that the preservice teacher be equipped with various classroom management styles otherwise teaching and learning will amount to an illusion. There will be poor performance on the part of the students where the academic performance of students is low especially in general mathematics, the curriculum content needed for the student to acquire before proceeding to the next academic level is hindered and this can result to students poor academic performance in mathematics. This study therefore sought to investigate the relationship between pre-service teachers' classroom management style and academic performance of senior secondary school students in general mathematics.

\section{Research Questions}

The following six (6) research questions were answered.

1. What is the influence of pre-service teachers' classroom questioning technique on students' academic performance in Mathematics?

2. What is the relationship between pre-service teachers' classroom leadership style and students' academic performance in Mathematics?
3. What is the influence of pre-service teachers' classroom interaction on students' academic performance in Mathematics?

4. What is the relationship between pre-service teachers' classroom task time scheduling and students' academic performance in Mathematics?

5. What is the relationship between pre-service teachers' classroom instructional technique and students' academic performance in Mathematics?

6. What influence does pre-service teachers' classroom organization have on students' academic performance in Mathematics?

\section{HYPOTHESES}

The following six null hypotheses were tested at 0.05 significant level.

Ho1: There is no significant relationship between pre-service teachers' classroom questioning technique and students' academic performance in Mathematics.

Ho2: There is no significant relationship between pre-service teachers' classroom leadership style and students' academic performance in Mathematics.

H03: There is no significant relationship between pre-service teachers' classroom interaction and students' academic performance in Mathematics.

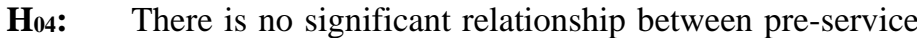
teachers' classroom task time scheduling and students' academic performance in Mathematics.

$\mathbf{H}_{05}$ : There is no significant relationship between pre-service teachers' classroom instructional technique and students' academic performance in Mathematics.

Ho6: There is no significant relationship between pre-service teachers' classroom organization and students' academic performance in Mathematics.

\section{Research Design}

The correlational survey research design was used in this study. This design was found appropriate because information was sought from pre-service mathematics instructors and the relationship between classroom management style and students' mathematical performance was explored,

\section{Population of the Study}

The study's population consisted of ninety-four (94) final year pre-service mathematics education teachers who took part in the first and second phases of practice teaching in the four tertiary institutions in Rivers State that present their students for teaching internship. The four tertiary institutions were Rivers State University, Ignatius Ajuru University of Education, University of Port Harcourt and Federal College of Education (Technical) Omoku.

\section{Sample and Sampling Technique}

A sample of ninety-four (94) final year pre-service Mathematics teachers was used for the study. The census sampling technique was employed to draw the sample. The census sampling technique was used because the population size of the study was small and therefore all the members of the population were used for the sample. 


\section{Instrument for Data Collection}

Two instruments were employed for this study namely:

1. 'Pre-service Mathematics Teachers' Classroom Management Questionnaire" (PMTCMQ)

2. "Mathematics Performance Test Grades Inventory" (MPTGI)

The researchers constructed an instrument titled "Pre-service Mathematics Teachers' Classroom Management Questionnaire" (PMTCMQ) that was used to collect data. The instrument was made up of two sections. Section A of PMTCMQ was designed to prompt information linked to the biography of the pre-service mathematics teachers. Section B of PMTCMQ was made up of thirty (30) items which measured the impact of pre-service mathematics teachers' classroom management styles on students' performance in mathematics.

Items 1 to 5 of PMTCMQ was designed to measure preservice teachers' classroom questioning techniques, items 6 to 10 measured pre-service teachers' classroom leadership style, Items 11 to 15 measured pre-service teachers' classroom Interaction, items 16 to 20 measured pre-service teachers' classroom task time scheduling, items 21 to 25 measured pre-service teachers' classroom instructional technique while items 26 to 30 measured pre-service teachers' classroom organization.

Items 1 to 5 were used to answer research question 1 and test hypothesis 1 , items 6 to 10 were used to answer research question 2 and test hypothesis 2 , items 11 to 15 were used to answer research question 3 and test hypothesis 3 , items 16 to 20 were used to answer research question 4 and test hypothesis 4 , items 21 to 25 were used to answer research question 5 and test hypothesis 5, and items 26 to 30 were used to answer research question 6 and test hypothesis 6. PMTCMQ was rated on a 4-point Likerts' rating scale of Strongly Disagree $(\mathrm{SD}=1)$ and Disagree
$(\mathrm{D}=2)$, Agree $(\mathrm{A}=3)$, strongly Agree $(\mathrm{SA}=4)$. The standard reference mean of PMTCMQ was 2.5.

The second instrument which was used for this study was the Mathematics Performance Test Grade Inventory (MPTGI) of the secondary school students which was administered to the students during the practice teaching exercise. The various test scores were collated and converted to percentage. The mathematics grades of students were gotten from the pre-service mathematics teachers. The MPTGI was designed to have three columns made up of serial number, name of students taught and the test scores of the students.

\section{Validity and Reliability of Instrument}

PMTCMQ was validated by three mathematics educators. The anomalies which were pointed out by each of the three experts in the instrument were corrected before administering to the sample. The split-half approach was employed to test PMTCMQ's dependability. PMTCMQ was given to ten pre-service students who did not engage in the main study once to complete. PMTCMQ had a reliability coefficient of 0.85 . Using the test retest approach, MPTGI was shown to have a reliability index of 0.72 .

\section{Method of Data Collection}

With the support of three research assistants, the researchers administered PMTCMQ to pre-service mathematics instructors. The instruments were given on a face-to-face mode and also retrieved on the same day from the respondents. The Mathematics test grades of the secondary school students were collated from the students' result dossier and entered into MPTGI.

\section{Method of Data Analysis}

The Pearson Product Moment Correlation statistical tool was used for analysis at 0.05 significant level.

\section{RESULTS}

Table 1: Summary of PPMC on the relationship between pre-service teachers' classroom questioning technique and students' academic performance in Mathematics.

\begin{tabular}{llccccc} 
Variables & $\mathbf{n}$ & r-value & $\mathbf{R}^{2}$-value & df & Sig. level & p-value \\
\hline $\begin{array}{l}\text { Classroom } \\
\begin{array}{l}\text { Questioning } \\
\text { Technique }\end{array}\end{array}$ & 94 & & & & & \\
& & 0.713 & 0.521 & 92 & 0.05 & 0.03 \\
$\begin{array}{l}\text { Mathematics } \\
\text { Performance }\end{array}$ & 94 & & & & & \\
\hline
\end{tabular}

The Pearson's product moment correlation on the association between pre-service teachers' classroom questioning method and students' academic achievement in Mathematics was significant and favourable, as seen in table 1 . The R-square value of 0.521 indicated that pre-service instructors' classroom questioning method contributed 52.1 percent to students' mathematical achievement. The Pearson product moment correlation revealed a significant link between pre-service teachers' classroom questioning method and students' performance in mathematics $(\mathrm{r}=$ $0.713, \mathrm{df}=92, \mathrm{p}=0.03<0.05)$. With a $\mathrm{p}$-value less than $0.05, \mathrm{H}_{\mathrm{O} 1}$ was rejected at a significant level of 0.05 . 
Table 2: Summary of PPMC on the relationship between pre-service teachers' classroom leadership style and students' academic performance in Mathematics.

\begin{tabular}{lcccccc} 
Variables & n & r-value & $\mathbf{R}^{2}$-value & df & Sig. level & p-value \\
$\begin{array}{l}\text { Classroom } \\
\text { Leadership }\end{array}$ & 94 & & & & & 0.01 \\
Style & & 0.683 & 0.485 & 92 & 0.05 & \\
$\begin{array}{l}\text { Mathematics } \\
\text { Performance }\end{array}$ & 94 & & & & & \\
\hline
\end{tabular}

The Pearson's product moment correlation on the association between pre-service teachers' classroom leadership style and students' academic achievement in mathematics was significant and favourable, as seen in table 2. The R-square value of 0.485 indicated that pre-service teachers' classroom leadership style contributed 48.5 percent to students' mathematics achievement.
The Pearson product moment correlation result demonstrates that there is a significant association between pre-service teachers classroom leadership style and students performance in Mathematics $(\mathrm{r}=0.683$, $\mathrm{df}=92, \mathrm{p}=0.01<0.05)$. With a $\mathrm{p}$-value less than 0.05 and at a 0.05 significant level, $\mathrm{H}_{\mathrm{O} 2}$ was rejected.

Table 3: Summary of PPMC on the relationship between pre-service teachers' classroom interaction and students' academic performance in Mathematics.

\begin{tabular}{lcccccc} 
Variables & $\mathbf{N}$ & r-value & $\mathbf{R}^{2}$-value & df & Sig. level & p-value \\
\hline $\begin{array}{l}\text { Classroom } \\
\text { Interaction }\end{array}$ & 94 & & & & & \\
& & & & & & 0.08 \\
Mathematics & 94 & 0.406 & 0.347 & 92 & 0.05 & \\
Performance & & & & & & \\
\hline
\end{tabular}

The Pearson's product moment correlation on the association between pre-service instructors' classroom interaction and students' academic achievement in mathematics was weak and positive, as shown in table 3 . The R-square value of 0.347 indicates that pre-service instructors' classroom interactions contribute 34.7 percent to students' mathematical achievement.
The Pearson product moment correlation result demonstrates that there is no significant link between pre-service instructors classroom interaction and students performance in Mathematics $(\mathrm{r}=0.406, \mathrm{df}=92, \mathrm{p}=0.08>0.05)$. With a $\mathrm{p}$-value larger than 0.05 , $\mathrm{H}_{\mathrm{O} 3}$ was retained.

Table 4: Summary of PPMC on the relationship between pre-service teachers' classroom task time scheduling and students' academic performance in Mathematics.

\begin{tabular}{lllllll} 
Variables & $\mathbf{N}$ & r-value & $\mathbf{R}^{2}$-value & Df & Sig. level & p-value \\
\hline $\begin{array}{l}\text { Classroom Task } \\
\text { Time Scheduling }\end{array}$ & 94 & 0.438 & & & & \\
\end{tabular}


Mathematics

Performance
94
The Pearson's product moment correlation on the association between pre-service instructors' classroom task time scheduling and students' academic performance in mathematics was weak and positive, as shown in table 4 . The R-square value of 0.251 indicates that pre-service instructors' classroom task time scheduling has a 25.1 percent impact on students' mathematics performance. The Pearson product moment correlation result demonstrates that there is a significant association between preservice instructors classroom task time scheduling and students performance in Mathematics $(\mathrm{r}=0.438, \mathrm{df}=92, \mathrm{p}=0.00<0.05)$. With a p-value less than $0.05, \mathrm{H}_{04}$ was rejected.

Table 5: Summary of PPMC on the relationship between pre-service teachers' classroom instructional technique and students' academic performance in Mathematics.

\begin{tabular}{llcrcrc} 
Variables & N & r-value & $\mathbf{R}^{2}$-value & Df & Sig. level & p-value \\
\hline $\begin{array}{l}\text { Classroom } \\
\begin{array}{l}\text { Instructional } \\
\text { Technique }\end{array}\end{array}$ & 94 & & & & & \\
& & 0.743 & 0.621 & 92 & 0.05 & 0.01 \\
$\begin{array}{l}\text { Mathematics } \\
\text { Performance }\end{array}$ & 94 & & & & & \\
\hline
\end{tabular}

The Pearson's product moment correlation on the association between pre-service teachers' classroom instructional approach and students' academic achievement in Mathematics was high and favourable, as shown in table 5. The R-square value of 0.621 indicated that pre-service instructors' classroom teaching approach contributed 62.1 percent to students' mathematical achievement.
The Pearson product moment correlation result demonstrates that there is a significant association between pre-service teachers classroom instructional approach and students performance in Mathematics $(\mathrm{r}=0.743, \mathrm{df}=92, \mathrm{p}=0.01<0.05)$. With a $\mathrm{p}$-value less than $0.05, \mathrm{H}_{\mathrm{O} 5}$ was rejected.

Table 6: Summary of PPMC on the relationship between pre-service teachers' classroom organization and students' academic performance in Mathematics.

\begin{tabular}{lcccccc} 
Variables & $\mathbf{N}$ & r-value & $\mathbf{R}^{2}$-value & Df & Sig. level & p-value \\
\hline $\begin{array}{l}\text { Classroom } \\
\text { Organization }\end{array}$ & 94 & & & & & \\
& & 0.841 & 0.620 & 92 & 0.05 & 0.04 \\
$\begin{array}{l}\text { Mathematics } \\
\text { Performance }\end{array}$ & 94 & & & & & \\
\hline
\end{tabular}

The Pearson's product moment correlation on the association between pre-service instructors' classroom organization and students' academic achievement in Mathematics was significant and favourable, as shown in table 6 . The R-square value of 0.620 indicated that pre-service instructors' classroom organization contributed 62 percent to students' mathematics achievement. The findings demonstrated a significant association between preservice teachers classroom arrangement and students' performance in Mathematics $(\mathrm{r}=0.841, \mathrm{df}=92, \mathrm{p}=0.04<0.05)$. With a $\mathrm{p}$-value less than $0.05, \mathrm{H}_{\mathrm{O} 6}$ was rejected.

\section{DISCUSSION OF FINDINGS}

Questioning skill is a valuable asset to the classroom teacher, the use of the chalk board and talking has been the long aged traditional method of teaching, but when questioning skill is integrated it promotes active participation in the teaching and 
learning process. The research question one revealed that preservice teachers' classroom questioning technique enhance student's performance as the result showed a $52.1 \%$ contribution of pre-service teachers' classroom questioning technique to students' academic performance in mathematics which shows a strong and positive relationship. The result agrees with the findings of Akpan (2018) and that of Tallabuna (2015) which revealed that effective questioning techniques improve students' performance. From their findings, questioning technique contributed $58.46 \%$ and $64 \%$ to students performance respectively. When subjected to statistical test, the result showed that there was a significant relationship between pre-service teachers' classroom questioning technique and students performance in mathematics. This also agrees with that of Akpan (2018). Yan and Patric (2012) found out that engaging students with high quality questioning skills, when appropriately used inspired curiosity and stimulated students' interest in learning thereby improving academic performance as well as classroom management.

The Pearson's product moment correlation on the association between pre-service teachers' classroom leadership style and students' mathematical performance was high and favourable, as shown in table 2 . The R-square value of 0.485 indicated that preservice teachers' classroom leadership style contributed 48.5 percent to students' academic success in mathematics. The findings demonstrated that there ws a link between pre-service teachers' classroom leadership style and mathematics academic achievement. The result agrees with the findings of George and Charles-Ogan (2020) which revealed that teachers' classroom leadership style significantly influenced students learning outcome in mathematics. The classroom leadership style of the teacher has a direct influence on students learning outcome. Applying the right leadership style enhances classroom management and conversely improve performance. This also agrees with Jamrok and Neisari, (2013) whose finding revealed that when the right leadership style is applied to the management of the classroom, there is a significant development in students' performance and growth.

The entire teaching and learning process has to do mainly with interaction between the teacher and the students, thus interaction is a basic component of the classroom. Table 3 showed that the Pearson's product moment correlation on the relationship between pre--service teachers and students performance in mathematics was weak and positive. The contact between teachers and students in the classroom is both poor and beneficial. The Rsquare value of 0.347 indicated that pre-service instructors' classroom engagement contributed 34.7 percent to students' academic success in mathematics. The finding also revealed that there was no link between pre-service instructors' classroom interactions and mathematics achievement. Every student is essentially a social being who interacts with their instructor and other classmates in their learning environment. One of the primary aims of the learning process is to develop the ability to socially engage. Despite the fact that classroom interaction is beneficial for classroom instruction, the result showed that there was no significant relationship between pre-service teacher classroom interaction and students' academic performance in Mathematics. This study contradicts that of Liaqat, Asif, Iqbal, and Khuda
(2011), who discovered that classroom interaction adds significantly to successful classroom teaching and atmosphere and leads to students' academic performance.

The Pearson's product moment correlation on the association between pre-service instructors' classroom task time scheduling and students' mathematical performance was weak and favourable, in this finding. The R-square value of 0.251 indicated that pre-service instructors' classroom task time scheduling contributed 25.1 percent to students' academic achievement in mathematics. When statistical tests were run on the data, it was shown that there was a link between pre-service instructors classroom task time scheduling and students' mathematics performance. The findings are consistent with those of Rettig and Canady (2013), who discovered a link between class scheduling and academic achievement. The task time schedule and the frequency of teaching can have an impact on student learning, instruction time and class timetable are inextricably linked. Bonner (2012) discovered that these variables they rely on each other.

The findings revealed a favourable link between pre-service instructors' classroom organization and the mathematical performance of learners. The R-square value of 0.620 indicated that pre-service instructors' classroom organization contributed 62 percent to students' academic success in Mathematics. The result of the statistical test revealed a substantial association between pre-service instructors' classroom arrangement and students' mathematics achievement. At a 0.05 significant level, the null hypothesis six $\left(\mathrm{H}_{\mathrm{O} 6}\right)$ was rejected. The importance of classroom structure to student academic achievement cannot be overstated. Guarino et al., (2015); Blazar and Kraft (2017) findings revealed that a well-managed classroom is associated to improved student performance. They went on to say that using a variety of organizational methods, such as creating a positive studenteducator environment, organizing, and using punishment and reward methods to ensure that the learning environment is conducive for learners, improved academic performance and created a well-structured learning environment.

\section{CONCLUSION}

The study concluded that various classroom management styles such as classroom questioning techniques, classroom leadership style, classroom instructional technique and classroom organization of the pre-service mathematics teacher have strong and positive relationship with students' performance in general mathematics and are significantly related except for classroom interactions and classroom task time schedule that are weak and positive.

\section{RECOMMENDATIONS}

It was recommended that pre-service mathematics teachers should be trained during micro-teaching on how and the need to address the issue of various anomalies which might emanate from the classroom during instruction using effective classroom management styles. 


\section{REFERENCES}

[1] Akpan, O.A. (2018). Relationship between teachers' classroom questioning technique and active learners. Rutledge.

[2] Blazar, D. \& Kraft, M.A. (2017). Teacher and teaching effects on students' attitudes and behaviors. www.Journals.sagepub.com

[3] Bonner, T. A. (2012).Comparison of the effects block and traditional schedules have on

[4] the number of students who are proficient on the biology end-of-course test in

[5] forty public high schools in the state of North Carolina. https://www.carol>bonner

[6] Ducharme, J. M., \& Harris, K. E. (2005). Errorless embedding for children with on-task and conduct difficulties: Rapport-based, success-focused intervention in the classroom. Behavior Therapy, 36 (3), 213-222.

[7] Ducharme, J. M., \& Shecter, C. (2011). Bridging the gap between clinical and classroom intervention: keystone approaches for students with challenging behavior. School Psychology Review, 40(2), 257-274.

[8] Francis, A., Philip, O. \& Francis, K. S. (2017). Perception of pre-service teachers' towards the teaching practice programme in college of technology education. University of Education, Winneba.Journal of Education and Practice. 8, (4), 156-163.

[9] George, N.R. \& Charles-Ogan, G.I. (2020). Impact of teachers' classroom leadership style on students' attitude towards learning of mathematics in Rivers State senior secondary school Nigeria. Proceedings of South Africa International Conference in Education 339 - 347.

[10] Guarino, C.M., Maxfield, M., \& Reckase, M.D., Thompson, P.N., \& Wooldridge, J.M.

[11] (2015).An evaluation of empirical bayes' estimation of value-added teacher

[12] performance measures. Journal of Educational and Behavioral Statistics, 40(2),190-222.

[13] Ismail, S.A.A. (2011). Student teachers' microteaching experiences in preservice English teacher education program. Journal of Language Teaching and Research, 2, 1043-1051. http://www.academypublication.com/issues/pastjltr/v

[14] Jamrok, H. \&Neisari, M. (2013). The study of the leadership style of secondary school teachers in Kuchesfehan region. International Research Journal of Applied and Basic Sciences, 4(5), 1057-1061

[15] Liaqat, H. Asif J., Iqbal A. \& Khuda, B. (2011) The effects of classroom interaction on students' academic achievement at secondary school level. www.mcser.org.

[16] Martin, N. K., \& Sass, D. (2010). Construct validation of the behavior and instructional management scale.
[17] Mayer, A.B. (2018). Equipping pre-service teachers in education. Owen \& Birds Press.

[18] Menenu S. P (2018). Classroom management and students' academic performance in public secondary schools in Rivers State. Journal of Scientific Research in Education 11, (5), 92-103.

[19] Patric, P. (2002). A comprehensive study identifying the most effective classroom management techniques and practices. The Dialogue, 10(4), 424433.

[20] Putri, D.M., Ferlya, E. \& Yusnila, Y. (2018). Pre-service teachers' performance post microteaching class in field experience program. Englisia Journal, 5(2), 102- 110. DOi: 10.22373/ej.v5i2.2889

[21] Rettig, M. D., \& Canady, R. I. (2013). Teaching in the block: Strategies for engaging self efficacy and their mathematics achievement African Journal of Educational Studies in Mathematics and Sciences 1, 167-173.

[22] Shafqat, A. \& Muhammad I.K. (2015). Assessment of teaching practice: Perceptions of students' performance in mathematics. International Journal of Developing Studies, 1(1), 60-68.

[23] Tallabuna, U.F. (2015). Impact of teachers' questioning technique on senior secondary students' performance in mathematics. Journal of Education and Developing Studies, 1(3), $78-88$.

[24] Ukandu, J. \& Kehinde, B.S. (2020). Effective and clinical microteaching in education. Tullips Publications.

[25] UNESCO (2021). Pre-service teacher training. http://uis.unesco.org>glossary-term

[26] Yan, Z. and Patric, P. (2012). Introducing questioning techniques to preservice teachers. Journal of Teacher Education and Educators 1, 159-184

\section{AUTHORS}

First Author - Akpobome, Enoh Jephthah, Department Of Curriculum Studies And Instructional Technology, Faculty Of Education, Ignatius Ajuru University Of Education Port Harcourt Rivers State Nigeria

Second Author - George, Nchelem Rosemary, Ph.D, Department Of Mathematics/Statistics, Faculty Of Natural And Applied Sciences,Ignatius Ajuru University Of Education Port Harcourt Rivers State Nigeria

Correspondence Author-nchelemgeorge@gmail.com 